However, the inauguration of this journal is important to librarians. It will be an aid in acquisitions work and cataloging-an invaluable reference tool in a scientific field which, heretofore, has had inadequate coverage.-Edward J. Doherty, Jr., Geophysical Research Library, Watertown (Mass.) Arsenal.

\title{
Library Education
}

Education for Librarianship. Papers Presented at the Library Conference, University of Chicago, August 16-21, 1948. Edited by Bernard Berelson. Chicago, American Library Association, 1949, 307p. $\$ 4.00$.

After nearly three decades of relative stability, education for librarianship has become an area of change and experiment. The flux of new thinking on library education has provided a theme for innumerable books, pamphlets, and periodical articles. It has been the subject of at least a score of conferences and meetings. As an area which reflects the whole complexity of the profession, each issue involved has found scores of highly vocal discussants frequently reflecting very differing points of view. As Dr. Berelson's "Introduction" to the report of this conference indicates, these new patterns of thought on library education as they have developed since I946 represent as significant a period as any other in our history. Library education very appropriately became, then, the subject for the conference of 1948 at the University of Chicago.

The particular contribution of this meeting to its subject lies in part in its three distinctive characeristics: first, in the preliminary determination to confine it to general problems of library education rather than to allow it to be dissipated in consideration of perhaps temporary experimentation; second, in the inclusion of library practitioners rather than the professional educator in presenting the subject; and third, in employing a discussant to bring some ready evaluation to each paper presented. This third device would seem to have gone far in bringing to the report of the conference more continuity of thought than is usually possible with such a medium.

Sixteen papers were presented at the conference, and these were arranged in five general groups. The first group on "General Education and Backgrounds" includes the role of the professional school, educational problems of allied professions and historical and foreign aspects of the subject. A second division, "Preparatory Education," was a paper on preprofessional education. The third group entitled, "Professional Education for Librarianship," included presentations of the problem peculiar to public libraries, academic institutions, service to children and youth, special librarianship, and a general summary of issues. The fourth, "Special Problems," included advanced study and research, clerical and subprofessional employment, and administrative problems of library education. The final group, "General Summaries," consisted of "The Non-Librarian Inquirer," (Robert D. Leigh); "The Practicing Librarian," (Luther H. Evans); and "The Library Educator," (J. Periam Danton).

A conference of such breadth carrying the differing theses of 16 major presentations and I I discussants is impossible to summarize. Some issues emerge, however, as providing the structure of basic problems of library education. These include: The stratification of library education (and a correspondent stratification of library positions); general library education as opposed to specialized library education; preprofessional and postprofessional education; the quality and number of library schools; the academic point at which various types of library education should occur, and the length of various types of programs; the relationship of library education to the field of practice; and the role of the Board of Education for Librarianship and other interested bodies.

Quite aside from its necessarily speculative nature, this conference follows a trend in a number of recent meetings where the presentation of problems is sharpened by definite recommendations and proposals. As Berelson points out, this conference had neither authority nor mandate to recommend action, yet from it come a body of specific proposals. These are:

I. That the number of library schools be sharply reduced in order to improve the quality of the remaining schools. 
2. That an exchange of senior personnel be effected between the schools and the practicing field of librarianship.

3. That a definite (and specified) system of training for the subprofessional and clerical workers in libraries be instituted, with all its implications for the profession generally.

4. That a research program in librarianship be planned, at least within each advanced school, for the most effective and economical development of knowledge in the field.

5. That library schools jointly develop a series of examinations to test the possession of a general education by the applicant for admission.

6. That library schools inaugurate a system of intensive (and specified) preparation for special librarianship.

7. That library schools reorganize their programs to take account of the concept of continuing education throughout the librarian's professional career.

8. That the basic specialized professional training of librarians working with the young (children's and young people's librarians in public libraries, school librarians, and teacherlibrarians) be the same.

The series of annual conferences sponsored by the Graduate Library School has provided a significant vehicle for the focusing of attention upon professional areas of major concern. The report of this last conference upholds the tradition of provocative and informed discussion of perhaps what is now the most critical area of the profession. To the body of recent literature and to other conferences on the subject, it provides perhaps the most complete general summary that has appeared to date. If one is to find fault with the report of the conference at all, it might lie in a regret for the overlong interval between the conference itself, and the publication of the printed volume covering it.-Kenneth R. Shaffer, School of Library Science, Simmons College.

Librarianship: Essays on Applied Bibliography. By Raymond Irwin. London, Grafton, 1949, 131p. 8s.6d.

Were this reviewer not a regular reader of the British library journals he might have taken Mr. Irwin seriously. For one might well get the impression from the initial chapters that while American librarians are still naively asking questions about library training their British colleagues have expertly found the answers. Judging from the articles, editorials and correspondence in the British journals it is evident that the pros and cons of library education are vigorously being debated there. In the field of library training, both in the United States and in England, educators are raising questions, seeking answers, and projecting further questions leading from the speculative answers. And so the unsuspecting reader of this book should not carry away the impression as cautioned above. Mr. Irwin does make some harsh statements but then rallies with such expressions as "These words are perhaps unfairly hard ..." More of his likes and dislikes later, however.

The author dissects the persistent American pursuit for a "philosophy" of librarianship and arrives at the conclusion that we are victims of some will-o'-the-wisp. For, as he sees it, there is no such thing. If there is no "philosophy" of librarianship, what are we seeking? Upon what foundation shall our programs of library education be based? $\mathrm{Mr}$. Irwin is of the opinion that we should seek the purposive directions in librarianship, the necessary underpinning, its locale, its limitations. Evidently he holds a very pragmatic view, for the one question which dominates throughout is: Will it work? That still begs the central question. Since we are an acaademic profession and, to be sure, the curriculum in library science is offered in an academic institution, there still remains the question: Do we know, at least, what shall be the corpus of knowledge which will provide the underpinning for prospective librarians? Quite simple. The answer is "applied bibliography." And, Mr. Irwin proceeds to define applied bibliography so that it includes precisely those subjects which constitute the traditional curriculum in American library schools. It is not quite up to date, however, for there is no provision for subjects which deal with reading interests and abilities or mass media of communication.

The author inflates his work in the very first sentence of the "Prologue," thus: "These essays grew out of a study of the writings of American librarians during the last 30 years on the subject of professional training for librarianship." This "study" consists merely of a few snatches from the works of Danton and Wheeler. No mention is made of the contributions of Williamson, Howe, Reece, 